\title{
Career Value Orientation of Psychology Students in Ho Chi Minh City
}

\author{
Phan Hong Nguyen, PhD. (Corresponding author) \\ University of Social Sciences and Humanities, \\ Vietnam National University of Ho Chi Minh City, Vietnam \\ E-mail: nguyen1975hongphan@yahoo.com
}

Received: September 4, 2016 Accepted: October 28, 2016 Published: January 4, 2017

doi:10.5296/ire.v5i1.10548ＵRL: http://dx.doi.org/10.5296/ire.v5i1.10548

\begin{abstract}
This paper presents the reality of career value orientation of psychology students in Ho Chi Minh City. The findings are: the career value orientation of this cohort falls in the level of "good". In order for students to have a stable career and good contribution to their future career, their career value orientation needs to fall in a higher degree - they need to obtain a full awareness of the economic, promotional, and moral aspects in career value orientation so that they will have proper attitude and behavior in career practice.
\end{abstract}

Keywords: career value orientation, psychology, students, Vietnamese universities, values

\section{Introduction}

The career value orientation of psychology students means the tendency of the subjects to choose those values that makes sense in their career and life via three levels: awareness, attitude, and action. In this research study, the career value orientation of psychology students are expressed through three aspects: economic value orientation, promotional value orientation, and moral value orientation. These are the three fundamental expressions in students' value orientation. The choice of these aspects at three levels, i.e. awareness, attitude, and action, comes from an initial survey of psychology students' value orientation and literature review.

Career value orientation is one of the issues raised by researchers in both theoretical and pratical terms. In the theoretical terms, students' career value orientation is expressed in some psychology theories such as: 1). The individualized model by David Tiedeman spells out two main phases in selecting and developing a career. They are the preparation phase and the implementation and adjustment phase (Le, Do, \& Mai, 2010); 2). The learning theory by Krumbolt $(1969,1976)$ conveys the author's opinion about the individual selection of career 
values. A remarkable in Krumbolt's theory is the encouragement of those in preparation and selection of careers to visit and do jobs at workplaces. By doing this, they will obtain more experience than mere diligent learning, research, or consultation in offices. Based on this, they will arrive at proper career values (Le, Do, \& Mai, 2010, p.15); 3). Platonop (1960) postulates a "Triangle of career orientation" which is composed of characteristics and requests of jobs in society, demand for human resources in the labor market, and characters as well as bio-psychological features of individuals. If the job found matches the three edges of this triangle, it is optimal and the individual who performs it arrives at proper career values. This triangular model has frequently been employed as the foundation in forming theoretical structures for studies of students' career value orientation (Dao, 2010). In a nutshell, the above-mentioned theories concentrate on the reasoning of the fashion invididuals make decisions in selecting careers for themselves. They presents the perspective that career value orientation is an open-ended and life-lasting process and a change in career value orientation may occur at any point in life. A common feature in these theories is that they are based on individual characters in a specific development phase and helps individuals at a specific point in time choose proper career values. These theories are also based on the processing of information, focus on the fashion individuals collect information and make decisions in selecting career values. Thus, the prioritized objectives in each theory ultimately contribute to individuals' selection of career values proper to themselves, family, and society.

In the practical term, there has been plentiful and diverse research studies in which researchers very much focus on the reality of career value orientation on different subjects via different aspects. Among these aspects are the scale of reality of career value orientation, career value orientation to variables such as gender, age, careers, and the relationship between career value orientation and personality, culture, and career achievement motives, etc.

With reference to the scale of career value orientation, there has been active participation by psychologists. They focus on constructing instruments, scale, and multiplechoice tests so as to conduct in-depth research and point out the reality of career value orientation and the factors which influence students' career value orientation. For example, the career values and skills scale, one of the top issues to researchers, comprizes 32 career values helping others, daily communication with others, cooperating with others, colleague relationship, competition, understanding things important to oneself, etc. Parsons, an American psychologist, employs tests and ankets to study students' competencies so as to help them arrive at proper career value orientation. Meanwhile, F. Galton, a British psychologist, helps students arrive at career value orientation by employing tests to diagnoze their personalities. As to employing multiplechoice tests, psychologists helps students see if their intended careers are proper or not. The results of these objective tests are the scientific foundations for them to reach proper career value orientation, to understand themselves more objectively, and to be able to select their proper study programs which ultimately motivates them in educational pursuit. Some of the multiplechoice tests advised are: Eysenck's personality test, Raven's continuous test, David Wechsler's general intelligence test, Zakarov's commuication test, Golomstoc's learning interests anket, Klimop's table of specifying a career on the basis of self-evaluation, Holland's RIASEC test, etc. 
With reference to the reality of career value orientation to variables such as gender, age, career, educational attainment, Perho, a Finnish psychologist, conducts the "Career orientation and pedagogical art in high school teacher education" study. The findings of the study show that in learning motives, teacher students more desire to achieve good grades than to become a good teacher. Predicated on this, he calls for a reorganization of the intake of students into teacher education programs. In the same vein, another Finish researcher, Volanen, seeks to undertand students' career value orientation and indicates the factors that influence their career value orientation. His findings show a stronger influence of subjective evaluation during the transition (from career training to work) on career value orientation than the transition itself. In addition, the influence of the initial working years hinges upon the career adaptation of each individual (Duong, 1996, p.15-19). Through their studies on the development of value orientation among senior high school and university students, Rubalkov and Volkova find that high school students have already had a strong development of career value orientation, especially towards the core activities to achieve objectives, which resembles career value orientation. As regards university students, career value orientation is very specific. That is, they have been able to specify the career values proper to themselves. The findings by the two researchers help educate career value orientation properly to senior high school and university students as well as to the development of individuals and society (Kon, 1987).

In "A causal model of career orientation and career choice of adolescent women", O'Brien and Fassinger (1993) based upon Fassinger's model of career choices presents their results on the relationship between career orientation and career choices among adolescent women. The sample in their study includes 409 adolescent women who were senior high school students at a female school in a central state of the U.S.A. This study points out the factors that predict career orientation and choices, including competence, self, attitude to sex role, and relationship with mothers. Female adolescents in the study who have an open attitude to sex role and close but independent relationship with their mothers tend to respect their own career choices. Those who have strong competencies and a high self tend to choose unconventional and high class careers (O'Brien, 1996). Fassinger (1985) in "A causal model of college women's career choice" conducts a study of 309 freshmen and sophomores. These subjects provide their information on work experience, academic performance, the influence of their role models, encouragement level by other people, attitude to work, attitude to self, attitude to sex role, interests and plans, and the practicality of career choices. The author finds that academic performance, success orientation and attitude to gender equality predict students' career orientation, which in return predicts their behavior in career choices (Fassinger, 1985).

With reference to the relationship between career value orientation and personality, culture, and career achivement motives, O'brien (1996) studies the influence of separation or parental attachment on 282 high school female students' self-efficacy, unanymoty, practicality and orientation of their careers. The scales employed in this study are "psychological separation" and "career self efficacy". In his article "The influence of psychological separation and parental attachment on the career development of adolescent women," the author finds that those who are attached with their mothers at an average level, base themselves on their mothers to resolve individual problems, feel emotionally attached with their mothers, and 
embrace a belief and attitude similar to those of their parents are those who have a strong self efficacy and have good career orientation as well as practicality (Raynor, 1970). Raynor (1970) in his article "Relationships between achievement-related motives, future orientation and academic performance" conducts two studies with a sample of 69 male and 52 female university students. He finds that students who have high achievement-related motives and low anxiety personality tend to perform better in the courses relevant to their future careers (useful courses) than in the irrelevant courses. In his first study, the author finds that students with high achievement-related motives and low anxiety personality and enrolled with useful courses achieve much higher than their counterparts (Rotberg, Brown, \& Ware, 1987).

Rottberg, Brown and Ware (1987) in their article "Career self-efficacy expectations and perceived range of career options in community college students" study the relationship between students' socio-economic background, race, gender, self-efficacy in career option and their orientation of sex role in career options. They find that students' interests and self-efficacy in their career option predict their career options. In "Effects of self-efficacy-enhancing interventions on the math/science self-efficacy and career interests, goals, and actions of career undecided college students", Luzzo, Hasper, Albert, Bobby and Martinell (1999) present the influence of the methods on university students' self-efficacy in career options, interests, objectives, and behaviors in career choices. These authors study the effects of academic performance and observational learning on the self-efficacy in career options and interests, objectives (or career aspirations) and behavior in study program options of those students who do not have clear orientation. In this study, those who have good academic performance but do not have career orientation are randomly placed into four groups: one under effects of academic performance, one under effects of observational learning, one under combined effects of academic performance and observational learning, and the other control group. The result shows that academic performance and the combination of academic performance and observational learning enhances students' self-efficacy in career options (Luzzo, Hasper, Albert, Bibby, \& Martinelli, 1999).

The above analysis of research studies in career values orientation can be concluded as follows. First, youths, especially students, are the target population that attracts most attention in studies of career value orientation, probably because it is an important issue in value orientation of young people. Second, the above-mentioned studies have constructed a theoretical framework on career value orientation. Based on this, researchers have diverted their focus to constructing a set of instruments to measure career value orientation, which has facilitated studies on different subjects under different approaches.

Researchers in Vietnam concentrate on resolving fundamental reasoning issues in career value orientation among high school students in particular and youths in general. Based on this, they specify an appropriate theoretical framework for research, construct a set of instruments, and study the reality of career value orientation on different subjects. In Vietnam, this line of psychological research may have developed for the most part in the following dimensions.

Regarding career value orientation to different activities, Le (2003) can be mentioned as a representative researcher. She conducts a study of career value orientation among those who are doing research in social sciences and humanities. In this study, this author analyzes the 
results at two levels: desire level and the practical activity level (i.e. the activeness in career activities). As the author posits, there are some differences in career value orientation among the subjects at the two levels. While the value orientation is more social at the desire level, it tends to be more individual at the practical activity level. In fact, the subjects in this study although be strong willed in their career, they spend more time and effort on income increment rather than career achievement (Le, Do, \& Mai, 2010). In his study "Value orientation of laborers in some enterprises in Hanoi", Nguyen (2012) also mentions the issue of career value orientation. The author seeks to understand the reality and degree of career value orientation at the 19/5 Textile Enterprise and Canon Vietnam. He especially studies the three aspects via which the subjects' value orientation is revealed: value orientation towards relationships with family, community, and other people, value orientation towards jobs and career, and value orientation towards individuals and the ideal self. Simultaneously, he points out the trends of value orientation development, the factors that influence laborers' value orientation, and jot down some socio-psychological recommendations for educating value orientation proper to the requests of Vietnam's social development and cultural and legislative norms in the era of openness and integration (Nguyen, 2012, p. 01 - 11).

Regarding relationships between personality traits and career value orientation, researcher points out that personality traits are strongly related with value orientation. Therefore, in researching the career value orientation of individuals, it is necessary to understand and evaluate precisely their personality traits via aspects such as career tendency (including aspiration, interests, and motives), competencies and abilities, and personality traits in career value orientation. Each individual when orienting him/herself toward certain career values needs to be aware of the world of work, demand for socio-economic development of the country, and demand for human resources within the relevant industry in order to specify a career properly (Dang, 2005). To help individuals understand themselves and find a proper career, Hoang Kien, Nguyen, and Pham (cite as Ministry of Education and Training, 1996) corroborate that individuals need to find an "optimal career choice domain" wherein they can answer all three questions: What career do I like? (interests), What career can I practice? (competence), and What career do I need? (social need, labor market demand). These are what the authors term "optimal career choice domain". In other words, interests and competencies are individual characteristics, which are basic elements to meet the demand of a certain industry. However, in order to find a proper career, these three elements are not sufficient, as it is essential that career seekers possess other characteristics such as ideology, value orientation, personality traits, awareness, etc. Apart from that, health and socio-economic background should also be considered.

In understanding personality traits in career value orientation, Nguyen (2005) lends attention to the formation of career characters. According to the author, career characters consist of four internal structures: career trends, career competencies, cognition and characters, and the others, such as personality traits, gender, age, etc. These four internal structures play an important role in directing career choices and employment (Nguyen, 2010). Employing a different approach to personality traits, from the regard of psychology and educational studies, Tran (2010) constructs a model of career characters, which encapsulates the issue of educational technology and stratification of career development phases in line with individual 
development of career characters compatible with each stage of career training in the education system. As posited by the author, this is the personality development and lifelong learning approach, for which the model of career characters is compatible with the phases: pre-career, career training, a career adjustment and development. The process of character development gradually refines individuals' characters by formulating new distinctive features, supplementing to existing ones, or developing them to a new degree.

Regarding the relationships between career value orientation and specific career values, in the thesis "Education of career values to students of culture and information majors", Do (2009) points out the reality of career value orientation of the subjects and presents recommendations for the their education of career values. This is an important issue, which makes sense in both theoretical and practical terms to enhance the quality of education and training of universities. The findings in Nguyen (2009) shows that students' career value orientation matches nine values described and researched in the state-funded project on career value. They are high paying, compatible with health and education, compatible with interests, conducive to family care, conducive to competence development, socially respected, life-tenured, useful to people, conducive to higher education. What's more, students choose a career that is intellect-intensive (Nguyen \& Pham, 2009, p. 70).

In seeking to understand students' awareness of career values, Lo (2010) in his study "Career value orientation of Son La high school students" career values", the author presents 30 career values which fall into three groups: socially necessary career values, family-needed career values, and individual-needed values. The author studied the interests of the subjects in career values by testing these 30 career values. Noticeable in this study is that interests cannot be excluded as a decisive criterion in career value orientation [Lo, 2010, p. 57 - 63 and p. 54 - 63]. Another researcher, Phung (2012), in her study "Orientation of Thai Nguyen ethnic high school students' career values", career value orientation consists of the following aspects: plans, reasons for career choices, career value orientation and career choice trends. In general, the career value orientation of ethnic high school students in Thai Nguyen reveals itself via specific value choices. The subjects mention 13 values. However, the scale of choice differs from value to value (Phung, 2012, p. 10 - 11 and p. 17).

In general, researchers in career value orientation in Vietnam have recently started their studies on different subjects. They have also studied the relationships between career value orientation and specific career values or personal characters. However, there have not any in-depth and systematic studies on psychology students' career value orientation. Students' career value orientation, in fact, exerts great influence on future human resources and socio-economic development. For this reason, research in psychology students' career value orientation in Vietnam is currently necessary and significant.

Psychology is a field of study in social sciences, which aims at understanding the formation principles of human psychology. It is used in the following basic realms: psychology research, psychology education, and applied psychology. Students of psychology are those who major in the psychology degree program. In Vietnam, psychology programs can be categorized into bachelor of psychology (basic psychology), bachelor of educational psychology (education), and bachelor of counseling psychology, etc.

In this study, psychology students' career value orientation is understood at three levels: 
awareness, attitude, and action. It is also tested through three basic orientation aspects: economic value orientation, promotional value orientation, and moral value orientation. In order to do arrive at these aspects at different levels, the authors employed the following specific values: stable life assurance, better-off life assurance, expertise enhancement, power of expertise, recognition, respect for law and personality, sharing information and helping colleagues.

\section{Research subjects and methods}

The research subjects in this study are students who major in psychology in Ho Chi Minh City. They come from the following universities: Ho Chi Minh City University of Social Sciences and Humanities, University of Teacher Education, and Van Hien University. The number of respondents in this study is 719 students. The author conducted an initial survey on 150 respondents and the official one on the rest.

In this study, the author collected data by with a questionnaire. In addition, the author also employs document analysis, Delphi, in-depth interviews, products of activity, case studies, and statistics.

\section{Results analysis}

\section{Overview of psychology students' career value orientation}

Before analyzing the expression aspects of psychology students' career value orientation, the author presents an overview of their career value orientation in the following table.

Table 1. Degree of expression of psychology students' career value orientation

\begin{tabular}{ccccc}
\hline No. & $\begin{array}{c}\text { Expression levels of psychology students' career value } \\
\text { orientation }\end{array}$ & $\boldsymbol{M}$ & $\boldsymbol{S D}$ & Rank \\
\hline 1 & Awareness of psychology students' career value orientation & 2.27 & 0.63 & 3 \\
2 & Attitude of psychology students' career value orientation & 2.39 & 0.62 & 1 \\
3 & Action of psychology students' career value orientation & 2.32 & 0,61 & 2 \\
\hline
\end{tabular}

In Table 1, psychology students' career value orientation registers at a nearly high degree. A comparison of expression levels shows that students' attitude to career value orientation registers at the highest degree $(\mathrm{M}=2.39, \mathrm{SD}=0.62)$, followed by their action $(\mathrm{M}=2.32, \mathrm{SD}=$ $0.62)$, and awareness $(\mathrm{M}=2.27, \mathrm{SD}=0.63)$, respectively. However, the difference in expression degrees is not significantly large.

The findings of this study supported by Jarlstrom's research (2000), in the research of the relationship between personality traits and vocational orientation of the students in Finland, Jarlstrom showed that students' career orientation of economic activity depended on the understanding ability of occupational at the highest level. For awareness, thus, the students 
were highly measured in their chosen careers. The career choices of students started from awareness to attitude and action, respectively.

\section{Expression degrees of psychology students' career value orientation}

Via awareness

The studied sample has proper awareness of career value orientation in all aspects: economic, promotional and moral. Their awareness registers at a nearly high degree. This is a positive sign and suits the current context of Vietnam's market economy and international integration of psychology. In this context, students' awareness of career value orientation is getting more practical.

Table 2. Psychology students' awareness of career value orientation

\begin{tabular}{clccc}
\hline No. & Aspects of awareness of career value orientation & $\boldsymbol{M}$ & $\boldsymbol{S D}$ & Rank \\
\hline 1 & Awareness of economic value orientation & 2.24 & 0.63 & 3 \\
2 & Awareness of promotional value orientation & 2.32 & 0.64 & 1 \\
3 & Awareness of moral value orientation & 2.26 & 0.63 & 2 \\
& Mean and standard deviation & $\mathbf{2 . 2 7}$ & $\mathbf{0 . 6 3}$ \\
\hline
\end{tabular}

As Table 2 shows, the economic aspect of career value orientation at the awareness level registers at the highest degree $(\mathrm{M}=2.32, \mathrm{SD}=0.64)$, followed by the awareness of moral value orientation $(\mathrm{M}=2.26, \mathrm{SD}=0.63)$ and the awareness of economic value orientation $(\mathrm{M}=2.24$, $\mathrm{SD}=0.63$ ), respectively. Although there is little statistical difference between these aspects at the awareness level, the registration of students' awareness of promotional value orientation at the highest degree is testimony to students' leaning against mental values rather than economic ones.

The results of Perho (1969) found that the motivation of students in the pedagogy area, they hope that they could receive good grade higher than become a good teacher and that mean toward the spiritual values of profession.

Via attitude

Table 3. Psychology students' attitude to career value orientation

\begin{tabular}{clccc}
\hline No. & Aspects of attitude to career value orientation & $\boldsymbol{M}$ & $\boldsymbol{S D}$ & Rank \\
\hline 1 & Attitude to economic value orientation & 2.44 & 0.66 & 1 \\
2 & Attitude to promotional value orientation & 2.38 & 0.60 & 2 \\
3 & Attitude to moral value orientation & 2.35 & 0.60 & 3 \\
\hline
\end{tabular}


In general, psychology students in the study have proper attitude to all aspects of career value orientation. They all register at a nearly high degree. For this reason, it is possible to state that they have positive attitude to their chosen careers.

A comparison of all aspects shows that the attitude towards economic value orientation registers at the highest degree $(\mathrm{M}=2.44, \mathrm{SD}=0.66)$, followed by the one towards promotional value orientation $(\mathrm{M}=2.38, \mathrm{SD}=0.60)$ and the other towards moral value orientation $(\mathrm{M}=2.35$, $\mathrm{SD}=0.60$ ). The statistics in Table 3 shows that students lend more weight to economic than promotional and moral values in their career orientation. At the level of attitude, these statistics seem to be in conflict with those in Table 2. However, it is plausible given that when students have positive attitude to economic values, they tend to work harder to enhance their expertise, accumulate knowledge, and conform to career ethics.

The research of Nguyen and Pham (2009) showed that students' career value orientation had agreeably selected at nine values of Science and Technology Program in the State level. The high-income occupations rated at the highest level and that is in favor of professional economic values.

\section{Via action}

Like the awareness and attitude of psychology students, their action on career value orientation registers at a nearly high degree.

Table 4. Psychology students' action on career value orientation

\begin{tabular}{clccc}
\hline No. & \multicolumn{1}{c}{ Aspects of action on career value orientation } & $\boldsymbol{M}$ & $\boldsymbol{S D}$ & Rank \\
\hline 1 & Action on economic value orientation & 2.42 & 0.63 & 1 \\
2 & Action on promotional value orientation & 2.28 & 0.62 & 2 \\
3 & Action on moral value orientation & 2.26 & 0.59 & 3 \\
& Mean and standard deviation & $\mathbf{2 . 3 2}$ & $\mathbf{0 . 6 1}$ & \\
\hline
\end{tabular}

As can be seen from Table 4, the economic aspect at the action level registers at the highest $(\mathrm{M}=2.42, \mathrm{SD}=0.63)$, followed by the moral aspect $(\mathrm{M}=2.26, \mathrm{SD}=0.59)$ and the promotional aspect $(\mathrm{M}=2.28, \mathrm{SD}=0.62)$, respectively. Based upon this, it is possible to state that psychology students have positive action on their future career. This is a proper career value orientation, which is a good preparation for their future.

Gerber, Wittekind, Grote and Staffelbach (2009) showed that there are three-type of career orientation, including: 1) traditional - promotion, 2) traditional - loyalty, and 3) independence - separation. The finding of Gerber et al. found that almost students choose the orientation of traditional - promotion.

\section{Relationship between the aspects of psychology students' career value orientation}

As the results of the study show, the economic, promotional, and moral aspects of career value orientation are well expressed at the levels of awareness, attitude, and action. In 
order to have a better understanding these aspects, we analyze the relationship between them to see if they are correlated or not. The Pearson coefficient of these aspects is illustrated in Figure 1.

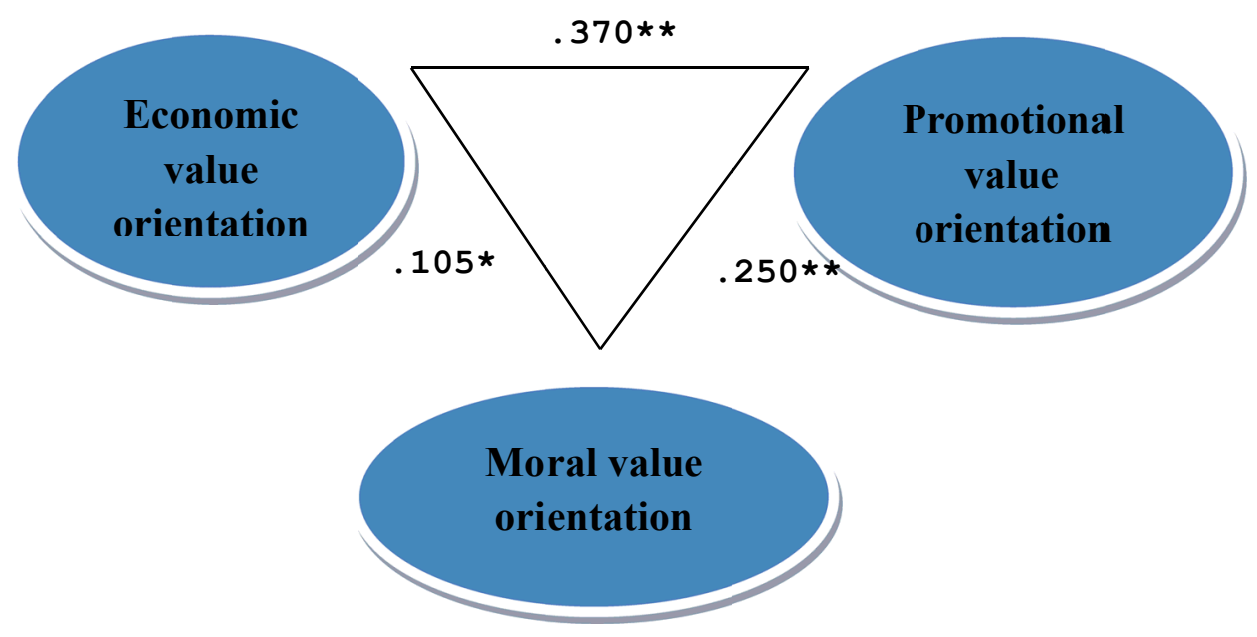

Note: $\mathrm{r}^{*}$ when $\mathrm{p}<0.05$ and $\mathrm{r}^{* *}$ when $\mathrm{p}<0.01$

Figure 1. Relationship between aspects of psychology students' career value orientation

As Figure 1 shows, there has a positive and strong correlation between the aspects of psychology students' career value orientation. The analysis of statistics in this study also indicates that the economic career value orientation is has a closer correlation with the promotional and moral value orientation than the correlation between these two aspects. This is a noticeable point, which necessitates attention in educating career values to students.

\section{Conclusion}

Psychology students' awareness of their career value orientation properly registers at a nearly high degree. In such awareness, there are many positive signs. If all aspects at the awareness level are compared, one can see that the promotional value orientation registers at the highest degree, followed by the moral value orientation and the eocnomic value orientation, respectively. There difference in degree between the aspects is not significantly large.

Regarding their attitude, psychology students' career value orientation also registers at a nearly high degree. At this level, their attitude to the economic value orientation registers at the highest degree, followed by the promotional value orientation and the moral value orientation. This signals that psychology students lean more against economic values than the others. However, these aspects are not significantly different in degree.

Like their awareness and attitude, psychology students' action on career value orientation also registers at a nearly high degree. If compared, their action on the economic career value orientation registers at the highest, followed by the promotional and moral value orientation. 
In general, the subjects in this study have proper and positive action on their future careers. As it has been mention elsewhere in this article, this is a good preparation.

Based on the literature review and emperical findings, the authors presents the following recommendations.

Firstly, psychology students' career value orientation should on average register at a higher degree so that they will find a career wherein they make good contributions. A higher degree of registration can be manifested in the following regards. One is that psychology students should have a full awareness of the economic, promotional, and moral aspects in their career value orientation. Such a fuller awareness will lead them to better-suited attitude and actions in their career practice. To achieve this, it is an onus on teachers and educators to raise students' awareness of their career value orientation. Another is that psychology students should have a harmonous attitude to all the aspects of their career value orientation. Lending too much or too little weight to a certain aspect may lead to unstable careers. The final thing is that the students should have proper actions in implementing their career values, which are first and foremost contingent on their learning efforts.

Secondly, the empirical findings put an alert that the moral value orientation among the subjects does not register as high as the other two. In fact, professional ethics are significantly important to those careers in the psychology field. It relates itself to human right assurance and personality respect. Failing to have adequate care about this aspect may lead to numerous psychological damages to people.

\section{References}

Dang, D. A. (2005). Tu vấn chọn nghề cho học sinh phổ thông [Career consultation for high school students]. Tạp chí Giáo dục, 121.

Dao, T. O. (2010). Nhũng kĩ năng sống cần giáo dục ở sinh viên Đại học Su phạm [Life skills to educate students at the University of Pedagogy]. Paper presented at the conference "20 years of Pschology and Education in Vietnam: achievements and prospects", Hà Nội, Việt Nam.

Do, N. A. (2009). Giáo dục giá trị nghề nghiệp cho sinh viên các chuyên ngành thuộc lĩnh vục văn hóa thông tin [Education of career values to students of culture and information majors]. Tp. Hồ Chí Minh: NXB ĐHQG

Duong, T. D. (1996). Định huớng giá trị của thanh niên sinh viên trong sụ nghiệp đổi mới ở Việt Nam [Value orientation among Vietnamese students in the reform context] (Associate $\mathrm{PhD}$. thesis in philosophy). Hà Nội: Viện Marx-Lenin và Tư tưởng Hồ Chí Minh.

Järlström, M. (2000). Personality preferences and career expectations of Finnish business students. Career Development International, 5(3), 144-154.

Fassinger, R. E. (1985). A causal model of college women's career choice. Journal of Vocational Behavior, 27(1), 123-153. 
Gerber, M., Witterkind, A., Grote, G., \& Staffelbach, B. (2009) Exploring types of career orientation: A latent class analysis approach. Journal of vocational behaviour, 75 , 303-318.

Kon I. J. (1987). Youth Psychology. TP. Hồ Chí Minh: NXB Trẻ.

Le, T. T. H., Do, T. L. H., \& Mai, V. T. (2010). Tu vấn hướng nghiệp cho học sinh Trung học phổ thông, thực trạng ở Việt Nam và kinh nghiệm Quốc tế [Career consultation for high school students: Vietnamese reality and international experience]. Hà Nội: NXB $\mathrm{KHXH}$.

Lo, M. T. (2010). Định hướng giá trị nghề của học sinh Trung học phổ thông, tỉnh Sơn La [Career value orientation of Son La high school students]. Tạp chi Tâm lý học, 139(10) $\& 143(3)$.

Luzzo, D. A., Hasper, P., Albert, K. A., Bibby, M. A., \& Martinelli Jr, E. A. (1999). Effects of self-efficacy-enhancing interventions on the math/science self-efficacy and career interests, goals, and actions of career undecided college students. Journal of Counseling Psychology, 46(2), 233-243.

Ministry of Education and Training. (1996). Sinh hoạt hướng nghiệp 11 [Career guidance 11]. Hà Nội: NXB Giáo dục.

Nguyen, D. T. (2010). Nhu cầu thị truờng lao động và sụ đáp ứng của giáo dục nghề nghiệp [Market demand and supply of vocational training]. Paper presented at the conference "20 years of Pschology and Education in Vietnam: achievements and prospects", Hà Nội, Việt Nam.

Nguyen, H. T. (2012). Định hướng giá trị của ngườ lao động trong một số doanh nghiệp trên địa bàn Hà Nộ [Value orientation of laborers in some enterprises in Hanoi]. Tạp chí Tâm lý học, 157(4), 1-11.

Nguyen, T., \& Pham, T. N. (2009). Tâm lý học Su phạm Đại học [University pedagogy psychology]. Hà Nội: HNXB Đại học Sư phạm.

O'Brien, K. M., \& Fassinger, R. E. (1993). A causal model of the career orientation and career choice of adolescent women. Journal of counseling psychology, 40(4), 456-469.

O'Brien, K. M. (1996). The influence of psychological separation and parental attachment on the career development of adolescent women. Journal of Vocational Behavior, 48(3), 257-274.

Phung, T. H. (2012). Định hướng giá trị nghề nghiệp của học sinh Trung học phổ thông là người dân tộc thiểu số ở tỉnh Thái Nguyên [“Orientation of Thai Nguyen ethnic high school students' career values]. Tạp chí Giáo dục, 291.

Raynor, J. O. (1970). Relationships between achievement-related motives, future orientation, and academic performance. Journal of Personality and Social Psychology, 15(1), 28-33. 


\section{Macrothink}

International Research in Education

ISSN 2327-5499

2017, Vol. 5, No. 1

Rotberg, H. L., Brown, D., \& Ware, W. B. (1987). Career self-efficacy expectations and perceived range of career options in community college students. Journal of Counseling Psychology, 34(2), 164-170.

Tran, K. D. (2010). Giáo dục và phát triển nguồn nhân lực trong thế kỷ XXI [Education and development of human resources in the 21th century]. Hà Nội: NXB Giáo dục.

\section{Copyright Disclaimer}

Copyright reserved by the authors.

This article is an open-access article distributed under the terms and conditions of the Creative Commons Attribution license (http://creativecommons.org/licenses/by/3.0/). 